Atıf Bilgisi: Atmaca, S. ve Akyol, M. (2021). Çocuk Youtuberların sosyal medyada oluşturduğu reklam içerikler. INIF E- Dergi, 6(2), 521-543.

\title{
ÇOCUK YOUTUBERLARIN SOSYAL MEDYADA OLUŞTURDUĞU REKLAM İÇERIKLER*
}

\author{
Safa ATMACA** \\ Doç. Dr. Mevlüt AKYOL *** \\ DOI: 10.47107/inifedergi.978976
}

Arastırma Makalesi $^{* * *}$

Başvuru Tarihi: 05.08 .2021

Kabul Tarihi: 11.11.2021

$\ddot{\mathbf{O} z}$

Günümüzde iletişim teknolojilerinin gelişmesiyle birlikte internete erişilebilirlik artmış, içinde bulunduğumuz bilişim çağıyla birlikte toplumun sosyal iletişimini, sosyal alanlarını ve sosyal etkileşimlerini önemli ölçüde etkilemiş, toplumu sosyal medya kullanımına yönlendirmiştir. Neredeyse her yaş grubunu etkisi altına alan sosyal medya, özellikle çocukların kullanım alanına girmiştir. Ebeveynleri başta olmak üzere çevresini gözlemleyen çocuklar, çocukluk dönemlerinde doğrudan veya dolaylı yollardan internete maruz kalmaktadır. Sosyal medya alışkanlıklarını küçük yaşta edinmiş olan çocuklar da sosyal medya kullanıcısı ve aynı zamanda kendi sosyal ağlarında kendi içeriklerini üretebilecek minik kullanıcılar haline gelmişlerdir. İçerik üretiminin, kolay ve ücretsiz olduğu sosyal ağlardan biri olan YouTube ise çocukların günlük yaşamlarında önemli bir yere sahip olmuştur. Kolay erişilebilirliği, ücretsiz oluşu ve çok fazla içeriğe sahip olması bakımından bir "İçerik Üreticiliğì" örneği olan YouTuberlık, sosyal medyada iz bırakma konusunda çocuklara cazip gelmektedir. Böylece sosyal medya ağı YouTube'da içerik üreticiliği yapan çocuklar "Çocuk YouTuber” unvanı alarak kendi istekleri veya ebeveynlerinin desteği doğrultularında sosyal medyada içerik üretebilmekte gerek sponsor desteğiyle gerekse farkında olmadan reklam unsuru içeren paylaşımlar yapabilmektedir. Çocuklar tarafindan üretilen ve herhangi bir mekanizma tarafından denetlenmeyen bu içerikler hem çocukları hem de hedef kitlesi olan çocuk takipçileri olumsuz etkileyebilmektedir.

$\mathrm{Bu}$ çalışma, çocukların çok küçük yaşta sosyal medya ile tanıştığını ve sosyal medyada reklam oluşturmak için içerik üreterek, sosyal medya reklamcılığına nasıl maruz kaldığını inceleme ve oluşturduğu bu içerikler içerisindeki reklamları analiz etme amacı taşımaktadır. Çalışmada nitel içerik analizi ve göstergebilimsel analiz tekniği yöntem olarak kullanılmış, "Oyuncak Avı”, "Vlad ve Nikita”, "Prenses Lina Tv”, “Ecrin Su Çoban” ve "Prens Yankl” çocuk kanallarının ürettiği reklam unsuru bulunduran içerikler analiz edilmiştir. Çalışmanın sonucunda, sosyal medyada çocuk kullanıcılar tarafından üretilen reklam içeriklerinin özellikle çocukların hedef kitlesine yönelik olduğu ve markalı içeriklerin cinsiyet gözetmeksizin incelendiği görülmüş ve böylece çocuk içerik üreticilerin markalı içerik tanıtımında önemli bir rol aldığ sonucuna varılmıştır. Çocukların sosyal medyada ürettiği içeriklerde reklam kullanımının kontrol edilebilmesi amacıyla bazı öneriler sunulmuştur.

Anahtar Kelimeler: Çocuk, YouTube, Çocuk YouTuber, Sosyal Medya, Kullanıcıların Ürettiği Reklamlar, Reklam

\footnotetext{
* Bu çalışma, İnönü Üniversitesi, Sosyal Bilimler Enstitüsü, İletişim Bilimleri ABD’de Doç. Dr. Mevlüt Akyol danışmanlığında hazırlanan "Çocuk Youtuberlarin Sosyal Medyada Oluşturduğu Reklam İçerikler" başlıklı yüksek lisans tezinden üretilmiştir.

** Bağımsız Araştırmacı, E-mail: safaaatmaca@gmail.com, ORCID ID: 0000-0003-4423-387X

*** İnönü Üniversitesi, İletişim Fakültesi, Halkla İlişkiler ve Tanıtım Bölümü, E-mail: mevlut.akyol@inonu.edu.tr, ORCID ID: 0000-0002-2195-1652

***** Yazar / yazarlar, makalede araştırma ve yayın etiğine uyulduğuna ve kullanılan fikir ve sanat eserleri için telif hakları düzenlemelerine riayet edildiğine yönelik beyanda bulunmuştur.
} 


\title{
ADVERTISING CONTENT CREATED BY CHILD YOUTUBERS ON SOCIAL MEDIA
}

\begin{abstract}
Today, with the development of communication technologies, accessibility to the Internet has increas Today, with the development of communication technologies, accessibility to the Internet has increased, and with the information age we live in, it has significantly affected the social communication, social areas and social interactions of the society, and has directed the society to the use of social media. Social media, which affects almost every age group, has entered the field of use especially for children. Children who observe their environment, especially their parents, have been exposed to the internet directly or indirectly during their childhood. Children who have acquired their social media habits at a young age have become small social media users who can produce their own content on their own social networks. YouTube, one of the social networks where content production is easy and free, has an important place in children's daily lives. Being an example of "Content Production" in terms of being easily accessible, free and having a lot of content, YouTuber appeals to children to leave a mark on social media. Thus, children who are content producers on the social media network YouTube can take the title of "Child YouTuber" and produce content on social media at their own request or with the support of their parents, and they can share advertisements with or without the support of sponsors. These contents, which are produced by children and not controlled by any mechanism, can negatively affect both children and their target audience.

This study aims to examine how children are exposed to social media advertising by producing content to create advertisements in social media and to analyze the advertisements in these contents. Qualitative content analysis and Semiotic analysis technique were used as methods in the study, "Oyuncak Avı", "Vlad ve Nikita", "Prenses Lina Tv", "Ecrin Su Çoban" and "Prens Yankı" children's channels containing advertising elements were analyzed. As a result of the study, it was seen that the advertisement contents produced by child users in social media were especially aimed at the target audience of children and branded contents were examined regardless of gender. Some suggestions have been made in order to control the use of advertisements in the content produced by children on social media.
\end{abstract}

Keywords: Child, YouTube, Child YouTuber, Social Media, User Generated Advertising, Advertising

\section{Giriş}

Teknolojinin gelişmesiyle birlikte internet hayatımızın birçok alanına etki etmeye başlamıştır. Sosyal medya ise hayatımızın önemli bir kısmında yerini almıştır. Geleneksel medyaya göre kendi içeriklerini kendileri üretebilen kullanıcılar, sosyal medyanın gelişmesiyle birlikte birer üreten tüketici olmuşlardır. Sosyal medya ağlarında içerik üretmeye başlayan bu kullanıcılar, etkileşimlerin artmasıyla birlikte birer influencer olmuş, ürettikleri içeriklerde reklam kullanmaya başlamışlardır.

Sosyal medyanın günlük hayatımıza hızlı bir şekilde ilerlemesi, çocukların sosyal medyada aktif bir rol oynamasını sağlamıştır. Yapılan araştırmalara göre, çocukların internete erişim yaşı 2'ye kadar düşmüştür (Çağıltay, 2016). Çocukların sosyal medyayı aktif olarak kullanması, onları sosyal medyanın birtakım dezavantajlarına karşı savunmasız hale getirmiştir. Bunun üzerine sosyal medya platformları üyelik, telefon doğrulama vs. gibi birtakım önlemler almış olmasına rağmen, çocuklar bu platformlara ebeveynlerinin telefonları üzerinden veya doğrudan desteği ile ulaşabilmektedirler. Video Paylaşım Platformu olan YouTube ise 2015 yılında YouTube Kids'i yayınlayarak, sosyal medyada yayınlanan içerikleri çocuklar için özel bir eğitim ve eğlence amacıyla filtrelemiştir (YouTube Kids Uygulamas1, 2018).

Sosyal medyada üretilen içerikler, özellikle çocukların dikkatini çekmiş, YouTuberlık mesleğini rol model olarak görmüş ve kendi istedikleri şekilde içerik üretmek istemişlerdir. İzleyici kitlenin çocuklar olduğu bu içerikleri yine çocuklar üretmeye çalışmışlardır. Çocukların ürettiği bu içerikler ise ebeveynlerinin yönlendirmesiyle gerçekleşmiş, çocuğun sosyal medyada mahremiyetini olumsuz etkilemiştir. 
Sosyal medyada çocuk, dünyada ve ülkemizde son yıllarda çok çalışılan bir konu olmasına rağmen sosyal medyada Çocuk Kullanıcıların Ürettiği Reklam İçerikler konusunda yapılan çalışmalar oldukça sınırlıdır. Bu çalışma ile öncelikle sosyal medya ve kullanıcıların oluşturduğu içerikler ile ilgili bir literatür çalışması yapılmış, ardından sosyal medyada reklam ve çocuk kullanıcıların oluşturduğu reklam içerikler üzerine, Çocuk Youtuber'ların ürettiği içerikler incelenerek göstergebilimsel ve nitel bir araştırma gerçekleştirilmiştir. Çalışma, çocuk kullanıcıların ürettikleri içeriklerde sosyal medya reklamcılığına nasıl maruz kaldığını inceleme ve oluşturduğu bu içerikler içerisindeki reklamları analiz etme amacı taşımaktadır. Bu kapsamda, çalışmanın ilk bölümü olan kavramsal çerçevede kullanıcıların ürettiği reklamlar oluşturmuş, sosyal ağlarda içerik üreticileri ve içerik türleri ele alınarak, Çocuk Kullanıcıların Ürettiği İçerikler ve reklam içerikler üzerine durulmuştur. Çalışmanın ikinci bölümünde ise "Oyuncak Avı", "Vlad ve Nikita", "Prenses Lina Tv", "Ecrin Su Çoban" ve "Prens Yankı" çocuk YouTuberların reklam unsuru içeren 1 video olmak üzere, toplamda 5 videosu göstergebilimsel analizi ve nitel içerik analizi yöntemiyle incelenerek bulgulara yer verilmiştir.

\section{Kavramsal Çerçeve}

Çalışmanın bu kısmında, kullanıcıların oluşturduğu içerikler ve çocuk kullanıcıların oluşturduğu içeriklerin yanı sıra ve çocukların sosyal medyada ürettiği reklam içeriklerden bahsedilecektir.

\subsection{Sosyal Medyada İçerik Üreticileri}

Web 2.0 teknolojisinin hayatımıza girmesiyle birlikte kullanıcılar içerik üretmeye başlamışlardır. $\mathrm{Bu}$ durum kullanıcıları hem üretici hem de tüketici haline getirmiştir. Sosyal medyayı geleneksel medyadan ayıran en önemli özelliklerinden biri ise kullanıcıların içeriklerini kendisi oluşturmasıdır.

Üreten Tüketici yani "prosumer" terimi ilk olarak 1980 yılında gelecek bilimci Alvin Toffler tarafından İngilizcede "üretici" anlamındaki "producer" ve tüketici anlamına gelen "consumer" kelimelerinin birleşmesiyle birlikte tanımlanmıştır (Kotler, 1986, s. 510). Bu durumda "Proconsumer" yani "üreten tüketiciler" sosyal medya ağlarında hem içeriği tüketen hem de üreten kişilerdir. Web 2.0'1n sosyal özelliklerinin gelişmesiyle birlikte kullanıcılar, pasif tüketiciden aktif üretici tüketiciye dönüşmüştür. Tüketicilerin üretim sürecine dahil olmasıyla birlikte, tüketim ve üretim arasındaki ayrım ortadan kalkmış 'üreten tüketici' ye dönüşmüştür (Charitsis, 2016, s. 37). Bununla birlikte üretüketicilerin(prosumer) ürettiği içerikler sosyal medya platformlarında artmasıyla birlikte içeriklerin üretim faaliyetlerini tanımlamak için "dijital emek" kavramını ortaya çıkmıştır (Çetin, 2019, s. 373).

User Generated Content'in Türkçe karş1lığ1 olan "Kullanıcıların oluşturduğu içerikler", tüketicilerin görüşleri ve yorumları doğrultusunda kullanıcıların ürettiği tavsiye, öneri, ürün ve markalar hakkında daha çok kullanıcının kişisel deneyimine dayanan yorumlara yönelik ürettiği içeriklerdir (Krishnamurthy ve Dou, 2008, s. 1).

"Kullanıcı tarafından oluşturulan içerik" terimi, 2005 ve 2006 yıllarında Web 2.0 fenomeni olarak öne çıkmış olan bir haber konusu olmakla birlikte, çevrimiçi platformlarda kullanıcılar tarafından oluşturulan içeriğin, ürün üzerindeki etkisi değişmiştir. Kullanıcıların oluşturduğu içerikler kullanıcıları da değiştirmiş, daha fazla içerikle ve daha fazla kullanıcı kontrolüyle oluşan modern kullanıcılar bağlanabilirliği arttırmıştır (Halbert, 2009, s. 926).

Kullanıcıların ürettiği içeriklerin en yaygın örnekleri arasında kurgusal karakterleri, film sahnelerini uyarlamak, markaların ürünlerini ve yayınlanmış reklamlarının 
parodilerini yapmak, popüler şarkıların sözlerini ve ritmini değiştirerek içerik üretmek gelmektedir. Sosyal medyadaki bu içerik üreticiler metinleri keserek, videolara şarkılar ekleyerek ve fotoğraf düzenleme programlarını kullanarak içerik üretebilmektedirler (Lessig, 2001, s. 10).

Kullanıcıların ürettiği içerikler konusunda kullanıcılar bazı durumlarda kendi içeriklerini kendileri üretebilmektedir. Örneğin kullanıcıların kendi imkanları doğrultusunda ürettikleri bir videoyu YouTube'a yüklemeleri ve kendi düşüncelerini blog sayfalarında paylaşmaları kullanıcıların ürettiği içeriklere örnek gösterilebilir (Çalışkan, 2014, s. 69).

Üreten Tüketicilerin, içeriklerini üretirken birbirinden ayrılmasını sağlayan birtakım unsurlar olabilir. Bu unsurlardan biri ise üreten tüketicilerin, yaş gruplarına göre kuşaklara ayrılması ve kendi kuşaklarına uygun şekilde içerik üretmesidir. Twenge ve arkadaşlarına göre (2010, s. 1118), Baby Boomer kuşağı 1946-1964 yılları arası, X kuşağı 1965-1981 arası, Y kuşağı 1982-1999 yılları arası, Z kuşağı ise 2000 yılından sonra doğan bireyleri kapsamaktadır.

Her yaşta ve kültürdeki insanlar gerek çevrimiçi olarak kullanıcı profillerini oluşturarak gerekse içeriklerini üreterek kendilerini istediği şekilde Sosyal medya ortamında ifade edebilmekte böylece hızlı ve küresel boyutta iletişimi rahatlıkla kurabilmektedirler. Sosyal medyanın tüm kuşaklardan kullanıcıları barındırmasıyla birlikte kuşaklararası benzerliklerin ve farklılıkların çevrimiçi ortamda incelenmesine olanak vermiştir (Ünal ve Deniz, 2020, s. 1293).

$\mathrm{Bu}$ durumda kullanıcıların ürettiği içerikler, sosyal medyada kullanıcıların herhangi bir şekilde dijital ortamda ürettikleri her içerik olabilmektedir.

\subsection{Sosyal Medyada Markalı İçerik Kullanımı ve İçerik Pazarlaması}

Günümüzde çağdaş tüketicilerin geleneksel medyadan sosyal medyaya gösterdikleri büyük ölçüdeki ilgi, şirketlerin varlıklarını kapsamlı bir şekilde çevrimiçi ortamlara inşa etmesine sebep olmuştur. Markalarını göstermiş oldukları bu ilgi, sosyal medya üzerinden üretilen içeriklerle içerik pazarlaması için yeni fikirler doğurmuştur.

Sosyal medyada içerikler genellikle ürün sayfaları, web siteleri, bloglar ve epostalar bültenlerindeki metinler olarak düşünülse de aslında sosyal medyada içerik kavramı çok daha geniş olmakla birlikte, tüketicilerin etkileşime girdiği her şey içerik olabilmektedir (Handley, 2014, s. 21). Sosyal medya pazarlaması ise çevrimiçi sosyal kanallar aracılığıyla bireylere web sitelerini, ürünlerini veya hizmetlerini tanıtma ve geleneksel reklam kanalları aracılığıyla mevcut olmayan çok daha büyük bir toplulukla iletişim kurma ve onlardan yararlanma yetkisi veren bir süreçtir (Weinberg, 2009, s. 13). Sosyal medyada içerik pazarlaması için önemli olan, tüketiciler için üretilen dikkat çekici içeriklerin yanı sıra, üretilen bu içeriklerin hangi marka tarafından üretildiği veya hangi markaya ait olduğu hakkında tüketiciye bilgi verilmesidir (Aksoy, 2018, s. 109). Sosyal medyanın, içerik alternatiflerinin artmasıyla birlikte, kullanıcıların sosyal medyada oluşturdukları içeriklerin kullanım amaçlarına göre sosyal medyada içerik pazarlamasına yöneldiği görülmektedir.

Mevcut yasal rejimde şiir, müzik, roman gibi eser niteliği taşıyan içerikler telif hakkıyla korunurken, sosyal medyada üretilen içeriklerin büyük kısmı ücretsizdir (Lessig, 2001, s. 105). Sosyal medyada pazarlığın devreye girmesi için kullanıcıların içeriği üretmesi, başarı sağlayabilmesi için ise doğru kişilere doğru içeriği doğru sosyal medya platformlar aracılığıyla dağıtılması, kullanıcıya sadık takipçilerin elde edilmesi gibi birçok konu bulunmaktadır (Weinberg, 2009, s. 15-16). 
Bununla birlikte, kaliteli bir içerik pazarlaması olmadan başarılı olunamayacağı gibi, sosyal medyada içerik pazarlaması, dijital pazarlamanın bugünü ve özellikle geleceği ve doğal olarak genel olarak pazarlamanın geleceği konumundadır (Baltes, 2015: 117).

\subsection{Markalı İçerikler (Branded Content)}

Markalı İçerik, markalar tarafından finanse edilerek oluşturulan görsel-işitsel veya dijital herhangi bir içeriktir (Asmussen, vd., 2016, s. 12). İçerik üreticileri tarafından üretilen içerikler, kısmen veya tamamen bir marka tarafından ödenir. Bir diğer değişle markalı içerikler, genel marka stratejisi olarak hazırlanan bir eğlence içeriğinin, reklam ve eğlencenin içine entegre edilerek sunulan bir pazarlama iletişimi ürünüdür (Horrigan, 2009, s. 51).

Göze çarpmayan bir teknik olan ürün yerleştirme, teknik olarak 19. yüzyıldan beri kullanılmaktadır (Newell vd., 2006, s. 579). Zamanla daha sofistike hale gelen bu tür teknikler, markaları teknolojik ortamda ürün yerleştirme faaliyetleri için yeni marka stratejilerine yöneltmiştir (Horrigan, 2009, s. 51).

Markalı içeriklerin birçok kullanım biçimi vardır. Kullanılan markalı içerikler, sosyal ağlar üzerinden üretilen birçok içerikle olmasının yanı sıra, geleneksel medyada da sık sık görülebilmektedir. Markalı içeri örneklerinden birçoğu Şekil 1'de sunulmuştur.

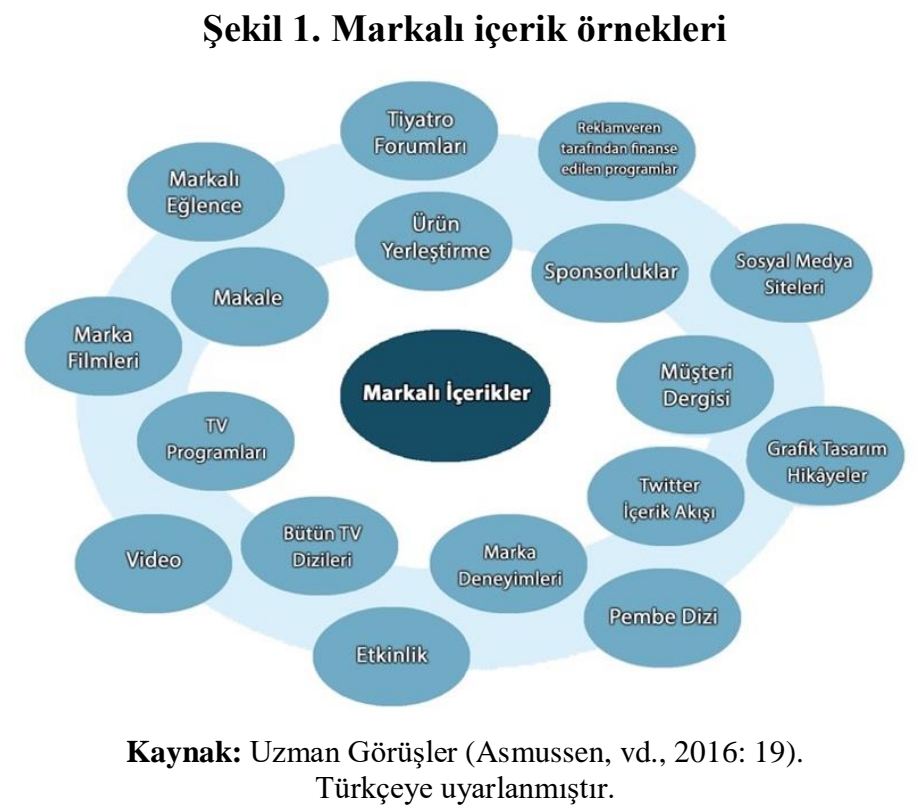

Yukarıda Şekil 1'de görüldügü gibi, Markalı içeriklerin birçok türü bulunmaktadır.

Markalı içeriklerin kullanımında bir diğer örnek ise Markalı İçerik Pazarlamasıdır. Takipçileriyle etkileşim kurmaya çalışan markalar, popüler hale gelebilecek görseller ve metinlerin yanı sıra ürettikleri içerikler ve tasarımlarla tüketicilere başarılı bir şekilde ulaşmak, tüketicileri etkileşime teşvik etmek gayretindedirler (Krakowiak ve Modlinski, 2020, s. 309). Markalı içerikler, markalı içerik kitlesine; ilgi çekici deneyimlerin yaratılmasını (eğlenceli, bilgilendirici, eğitici vb.), ihtiyaçlar, istekler, ilgi alanları veya izleyicinin tutkuları, yüksek kaliteyi, şeffaflık ve özgünlügü, müdahaleci olmayan / incelikli olma (her ikisi de yumuşak satış /bağlama bağlı olarak zor satış mümkündür), ilgi çekici anlatıları ve paylaşılabilirliği sunmaktadır (Asmussen, vd., 2016, s. 30).

Markalı içerikler, marka sahibine ise kitlelerin ilgisini yüksek oranda çekmek, uzun vadeli olarak markasını inşa etmek, yeni kitleler oluşturmak ve beslemek, tüketici ile etkileşimi teşvik etmek, güven inşa etmek ve inanılırlığı artırmak, bağlılık oluşturmak ve 
müşteriyi elde tutma oranını artırmak, düşünce liderliği inşa etmek, marka için (daha fazla) kültürel alaka yaratmak gibi firsatlar sunmaktadır (Asmussen, vd., 2016, s. 31). Bu durumda markalı içerik pazarlaması, günümüzde markalar tarafından oldukça tercih edilmektedir.

Markalı içerik pazarlamasında bir diğer önemli nokta ise markalı içeriklerde reklam kullanımıdır. Markalı içeriklerin dijital popülaritesi, genellikle markaların sosyal medya hesaplarındaki beğeni sayısı, markayla ilgili yorumlar ve markanın hayranları olan çevrimiçi kullanıcılar tarafından gerçekleştirilen paylaşımlardır (Krakowiak ve Modlinski, 2020, s. 309). Bu paylaşımlar etkileşim aldığı için markalar tarafından ürün yerleştirilerek kullanılabilmektedir. Bu ise günümüzde pazarlama başarısı olarak sosyal medyanın en temel göstergelerinden biri haline gelmiştir.

Bazı durumlarda markanın oluşturduğu içeriklere kıyasla, influencerlar tarafından üretilen markalı içerikler daha organik ve otantik göründüğünden tüketiciler tarafından daha dikkate alınmaktadır (Lou ve Yuan, 2019, s. 58). Bu durumda bazı markalar, özellikle reklam içerik üretirken, influencerlarla birlikte iş birliği yapabilmektedirler.

\subsubsection{Kullanıcıların Oluşturduğu Markalı İçerikler}

Sosyal medyada kullanıcıların içerik üretmeye başlamasıyla birlikte, ürettikleri içerikleri de kendi amaçları doğrultusunda kullanmaya başlamışlardır. Bu durumda üreten tüketiciler, aktif olarak reklam sektöründe yer almış, reklam sektörü için sponsorlu içerikler üretmeye başlamışlardır.

Tüketicilerin herhangi bir ürün, marka veya kampanya hakkında paylaştıkları görüşleri ve deneyimleri, bu içeriklere anında ulaşan tüketicilerin bu ürün/marka ile birlikte kurmuş oldukları ilişkiyi çok geliştiren bir noktaya getirmiştir. Böylelikle, kullanıcıların ürettiği içerikler kapsamında, sosyal medyada yeni bir reklamcılık ortaya çıkmakta ve “Üreten Tüketici Reklamcılığı” olarak kullanılmaktadır (Güney, 2010, s. 253).

\subsection{2. Çocuk Kullanıcıların Oluşturduğu Markalı İçerikler}

Üreten Tüketicileri bir başka örnek olarak çocuklar gösterilebilir. Sosyal medya platformlarının popülerliğinin artmasıyla birlikte, internet kullanımının yaş oranı düşmüştür. 6-15 yaş arasındaki çocukların internet ve bilgisayar kullanımı üzerine yapılan bir araştırmada, Türkiye'de 6-15 yaş arasındaki her 10 çocuktan 7'sinin internet kullandığı, internet kullanım oranının ise çocuklar içerisinde \%70'i aştı̆̆ sonucuna varılmıştır (Habertürk, 2019). We Are Social ve Hootsuite (2020, s. 20)'in iş birliği ile hazırladığı "Digital 2020 in Turkey" isimli raporunda '2020 Y1lı Türkiye İnternet ve Sosyal Medya Kullanım İstatistikleri' paylaşılmış, bu rapor sonuçlarına göre ise Türkiye'de toplam nüfusun \%74'ü internet ve \%64'ü aktif sosyal medya kullanıcısıdır. 13-17 yaş arası nüfusun yaklaşı \% $\% 3,4$ 'ü de sosyal medya kullanıcısı olarak raporlanmıştır.

Çocukların reklam kullanımına ilişkin olarak 10.01.2015 tarih ve 29232 sayılı Resmî Gazetede yayınlanan “Ticari Reklam ve Haksız Ticari Uygulamaları Yönetmenliği”nin "Reklamlarda Çocuklara İlişkin Düzenlemeler" başlığının 1. fikrasının b) bendinde "Hedef kitlesindeki çocukların yaş grubunun özellikleri dikkate alınarak, çocuklarda gerçek dış1 beklentilere neden olan veya kurgu ile gerçeklik arasındaki farkı ayırt etmeyi zorlaştıran unsurlar içeremez." denilmektedir (Resmî Gazete, 14.06.2021) Bu maddeye göre, çocukların oluşturduğu veya çocuklar için oluşturulan içeriklerde kurgu ile gerçeklik arasındaki farkı ayırt etmeyi zorlaştıran içeriklerin üretilmesinin yasal olarak önüne geçilmiştir. 
Çocukların sosyal medyayı kullanma alışkanlıkları, çocukların ilgisini çekecek içeriklerin üretilmesiyle birlikte artmaktadır. Çocuk tüketicilere uygun içerikler, yine çocuklar tarafından üretilebilmektedir. Çocukların ürettiği içerikler ise yine çocuk kullanıcılar tarafından izlenmektedir. Küçük yaşlardan itibaren sosyal medya platformlarını kullanmaya başlayan çocuklar, sosyal medya hesaplarına sahip olmakta ve bu hesaplar üzerinden içeriklerini üretmektedirler. Üretilen içeriklerin büyük bir kısmı ebeveynlerin yönlendirmesiyle, destekleriyle ve yardımlarıyla gerçekleşmektedir. Çocukların ürettikleri içeriklerin ilgi çekici olması, etkileşimi arttırdığı için ebeveynler çocuklarına ait çevrimiçi kimlikler oluşturmaktadır. Oluşturulan bu kimlikler, çocukların adına ebeveynleri tarafından yönetilmektedir (Leaver, 2015, s. 149). Özellikle, etkileşim gerektiren sosyal medya platformlarını tercih eden ebeveynler, çocukları için oluşturdukları sosyal medya ağlarında çocuklarını küçük birer içerik üreticisine çevirmektedir. Sosyal medyada içerik üreten çocuklar, özellikle okuma veya yazma gerektirmeyen, video içeriklere yönelmektedirler. Çocuk kullanıcılar tarafindan oluşturulan video içerikler, özellikle çocuk tüketiciler tarafından ilgi uyandırmakta ve izlenmektedir. Etkileşimin artmasıyla birlikte, platformlar içerik üreticilerine reklam karşılığında bir bedel vermekte, bu alınan bedel ise ebeveynleri tarafindan kontrol edilmektedir.

Sosyal medyada içerik üreten çocuklar, bu ürettikleri içeriklerde doğrudan veya dolaylı yoldan reklam unsuru paylaşabilmektedirler. Bu üretilen içeriklerin büyük bir kısmı ebeveynlerinin kontrolünde olduğundan, oyuncak, yiyecek veya giyim gibi sponsorluklar çocuklar tarafından içeriğe dönüştürülebilmektedir.

Özellikle son dönemlerde gerek yurt dışında gerekse ülkemizde çocukların bir "Sosyal Medya Fenomeni” olarak içerik ürettikleri görülmektedir. Çocuklar ürettikleri içeriklerle birkaç farklı şekilde "Infuluencer Marketing" faaliyetlerinde yer almaktadır. Özellikle ebeveynleri influencer olan çocuklar, fenomen anne-babalarıyla birlikte içerik üretmekte, birer aile influencer'1 olmaktadırlar (Atalay, 2019 s. 186).

\section{Metodoloji}

$\mathrm{Bu}$ başlık altında; araştırmanın amacı ve önemi, araştırma soruları, evren ve örneklemi, araştırma yöntemi ile verilerin toplanması ve çalışmanın sınırlılıkları yer almaktadir.

\subsection{Araştırmanın Amacı ve Önemi}

Günümüzde sosyal medya platformlarının oldukça popüler bir olgu haline gelmesiyle birlikte, her yaş grubundan kullanıcının medyayı kullanma ve içerik üretme oranının arttırdığı ve gün geçtikçe önem kazandığı görülmektedir. Çoğunlukla ebeveynlerinin denetiminde sosyal medya platformlarını kullanan çocuklar, içerik üretimi konusunda da kolayca bilgi edinebilmektedirler. Bu araştırmanın amacı; sosyal medyada içerik üreten çocuk kullanıcıların, ürettikleri içeriklerin belirlenmesi ve bu içeriklerdeki reklam kullanım faaliyetlerini incelemek ve değerlendirmektir. Bir başka ifadeyle çocuk içerik üreticilerin, video içerikleri içerisinde reklamı nasıl ve nerede konumlandırdıklarını analiz etmek çalışmanın temelini oluşturmaktadır. Bu kapsamda Çocuk YouTuber'ların ürettiği içeriklerindeki reklamlar incelenerek, sosyal medyayı henüz küçük yaşta nasıl reklam aracı olarak kullandıkları ve ürettikleri içeriklerin nasıl reklam odaklı olduğunun anlaşılması amaçlanmaktadır.

$\mathrm{Bu}$ çalışma, Çocuk İçerik Üreticilerin içeriğindeki reklam kullanım oranlarını incelediğinden, elde edilen bulgular 1şığında çocukların reklam kullanım çalışmalarına yol gösterme açısından önem arz etmektedir. Elde edilen bulgular, sosyal medyada bir içerik üreticisi olan çocukların, ürettiği içeriklerin türlerinin değerlendirilmesi için önemlidir. 


\subsection{Araștırma Soruları}

1) Çocuk YouTuberlar video içeriklerini reklam unsurunu ortaya çıkaran kelimeler kullaniyor mu?

2) Çocuk YouTuberlar, video içeriklerinde reklam kullandıklarının farkında mı?

3) Çocuk YouTuberlar video içeriklerinde, sponsorlu reklam içerikleri üretiyor mu? $\mathrm{mu}$ ?

4) Yapılan yasal düzenlemeler Çocuk YouTuberların içerik üretimine etkisi oluyor

5) Üretilen video içeriklerde, reklam olduğunu belirten standartları karşılıyor mu?

6) Ebeveynlerin yönlendirmesiyle üretilen içerikler Çocuk YouTuberların mahremiyetini ihlal ediyor mu?

7) Sosyal medya üzerinden yapılan reklamlarda alınan hukuki önlemler çocukları yeterince koruyor mu?

\subsection{Araştırma Evren ve Örneklem}

Çalışmanın evrenini, sosyal medya platformu YouTube'daki tüm çocuk video içerik üreticileri oluşturmaktadır. Araştırmanın örneklemi ise, tesadüfî örneklemedir. 1 milyon ve üzeri abone sayısına sahip olan 25 Çocuk YouTuber arasından rastgele seçilen 5 çocuk YouTuber'ın ürettiği video içerikleridir. İçerikler, amaçsal olarak seçilmiş reklam unsuru bulunduran 1 videoyu kapsamaktadır.

$\mathrm{Bu}$ çalışmada evren ve örneklem seçimi yapılırken sosyal medyada içerik üreticilerinin sayısının artması ve internet kullanımının yaş oranı düştükçe çocuk kullanıcıların da internet erişilebilirliğine sahip olması, seçilen YouTube kanallarının ise çocuk profiline sahip olması, abone sayısı, izlenme sayısı göz önünde bulundurulmuştur. YouTube'un dünyada ve ülkemizde her geçen gün kullanımının artması, içerik üretiminde bir sınırlama görülmemesi ve abone sayısının artmasıyla sponsorlu reklam kullanılabilirliğinin olması nedeniyle örneklem olarak uygun görülmüştür. YouTube seçilmesinin sebebi ise çocukların içerik yüklemeleri için herhangi bir okuma ve yazma bilgisine ihtiyaç olmadan rahatlıkla içerik üretebilmeleridir.

\subsection{Araştırma Yöntemi}

Bu çalışmada araştırma yöntem olarak göstergebilimsel analiz ve nitel içerik analizi tekniği kullanılmıştır. Krippendorffa göre içerik analizi, veriden onun içeriğine ilişkin tekrarlanabilir ve geçerli sonuçlar çıkarmak üzere kullanılan bir araştırma tekniğidir (Krippendorff 1980, s.25'dan aktaran Koçak \& Arun, 2006). Nitel içerik analizi ise insan davranışları ile ilgili kaynaklardaki mesajları analiz edebilmek için kapsamlı materyallerin tamamının düzenlenmesi gerektiren, doğrudan olmayan yollarla insan doğasını ve davranışlarını belirleme üzerinde çalışmaya imkân tanıyan bir tekniktir (Büyüköztürk vd., 2008, s. 240). Çalışmada kullanılan video içerikleri, Roland Barthes'ın göstergebilimsel analiz için faydalandığı düzanlam ve yananlamlar içerik ve biçim kavramlarından yararlanılarak ele alınmıştır. Her nesnenin, içeriğin, görüntünün ve mesajın farklı anlamları vardır. $\mathrm{Bu}$ olgular birbirinden farklı birçok gösterge içermektedir. Mesajda aktarılmak istenilen konu ile göstergeler doğru olarak seçildiğine veya göstergeler düzgün bir şekilde anlamlandırıldığında içeriğin anlatmak istediği mesajı algılama daha kolay olmaktadır (Barthes, 1986, s. 33-36'dan akt. Öztürk, 2014, s. 88). Nitel içerik analiz yöntemi, çocukların ürettiği video içerikteki reklamı, göstergebilimsel analiz ise üretilen içeriklerde kullanılan reklamın kullanımı ve içerikte markaya yüklenilen anlamlar ve markanın imajı hakkında verdiği bilgileri ortaya çıkarmak için yapılan doğru bir yöntemdir. 
Çalışmada video platformu olan YouTube'da 1 milyon ve üzeri abone sayısına sahip olan 25 çocuk kanalı arasından 5 çocuk kanalı rastlantısal olarak seçilmiştir. Seçilen 5 Çocuk YouTuber kanalında bulunan içeriklerden amaçsal olarak reklam unsuru bulunan 1 video, toplamda 5 video seçilerek reklam içerikler belirlenmiştir. Çocuk YouTuberların, YouTube Kanalları üzerinden yayınladıkları reklam unsuru bulunan bu video içeriklerin ana teması, uzunluğu, marka, karakter, kurgu, ses ve tekrarlanan ifadeler nitel içerik analizi biçiminde çözümlenmiştir. Sonrasında, göstergebilimsel analiz yönteminden yararlanarak

\begin{tabular}{|c|c|c|c|c|c|c|}
\hline & $\begin{array}{c}\text { ÇOCUK } \\
\text { YOUTUBER }\end{array}$ & $\begin{array}{c}\text { TOPLAM } \\
\text { ABONE } \\
\text { SAYISI }\end{array}$ & $\begin{array}{l}\text { TOPLAM } \\
\text { İÇERIK } \\
\text { SAYISI }\end{array}$ & $\begin{array}{c}\text { TOPLAM } \\
\text { REKLAM } \\
\text { SAYISI }\end{array}$ & $\begin{array}{c}\text { TOPLAM } \\
\text { İZLENME } \\
\text { SAYISI }\end{array}$ & $\begin{array}{l}\text { KATILMA } \\
\text { TARIHII }\end{array}$ \\
\hline 1 & Oyuncak Avı & 15.205 .432 & 492 & 42 & $7,676.625 .851$ & 29 Aralık 2014 \\
\hline 2 & Vlad ve Nikita & 1.891.925 & 266 & 59 & 799.951.091 & 11 Mart 2019 \\
\hline 3 & Prenses Lina Tv & 1.882.632 & 458 & 66 & 1,580.091.132 & 6 Ağustos 2017 \\
\hline 4 & Ecrin Su Çoban & 1.641.359 & 588 & 24 & 714.092.338 & 4 Ocak 2016 \\
\hline 5 & Prens Yankı & 1.292 .452 & 636 & 214 & 643.440 .273 & 21 Ağustos 2015 \\
\hline
\end{tabular}

görsel içeriklerin aktardığı anlam biçim, içerik, düzanlam ve yananlam birleşik boyutlarında incelenerek reklam iletilerinin ne tür dilsel/görsel göstergelerden yararlanarak anlam aktardıkları incelenmiştir.

Çalışma kapsamında içerikler; "Oyuncak Avı", "Vlad ve Nikita", "Prenses Lina Tv", "Ecrin Su Çoban", ve "Prens Yankı" çocuk kanallarının" reklam içerik unsuru bulunduran ve amaçsal olarak seçilen 1 video ile sınırlandırılmıştır. Araştırmada Çocuk YouTuberların abone sayısının 1 milyon ile sinırlandırılmasının sebebi, sponsorlu reklam içerik üretebilmek için yeterli abone sayısına sahip olmalarıdır.

\section{5. Çocuk YouTuberların Ürettikleri Reklam İçeriklere İlişkin Bulgular}

Reklam içeriklerine ilişkin bulgularda, Çocuk YouTuberların ürettiği reklam içeriklere ilişkin bulgular paylaşılacaktır.

\section{Tablo 1. Çocuk YouTuberların Kanal Analizleri}

Yukarıda YouTube Türkiye'de 5 Çocuk YouTuber kanalının toplam abone sayısı, içerik sayısı, reklam sayısı, izlenme sayısı ve YouTube'a katılma tarihleri bulunmaktadır.

Tablo 2. Çocuk Youtuberların İçeriklerine İlişkin Bulgular

\begin{tabular}{|c|c|c|c|c|c|}
\hline $\begin{array}{c}\text { Çocuk } \\
\text { Youtuber }\end{array}$ & PAYLAŞIM & TARIH & IZZLENME & LIKE & DISLIKE \\
\hline Oyuncak Avı & $\begin{array}{c}\text { ÖYKÜ NUM NOMS } \\
\text { TUTKUSU learn colors with } \\
\text { me and watch num noms - } \\
\text { Play Time }\end{array}$ & 25 Şubat 2018 & 8.146 .720 & - & - \\
\hline $\begin{array}{l}\text { Vlad } \\
\text { ve } \\
\text { Nikita }\end{array}$ & $\begin{array}{c}\text { Vlad ve Niki Oyuncak } \\
\text { kamyonlarla eğleniyor | Hot } \\
\text { Wheels Canavar Kamyonlar }\end{array}$ & 15 Mayıs 2021 & 165.787 & 1895 & 870 \\
\hline $\begin{array}{c}\text { Prenses Lina } \\
\text { TV }\end{array}$ & $\begin{array}{c}\text { Danone Mix Yiyen Lina'nın } \\
\text { Elbisesi Frozen Elsa } \\
\text { Kostümlerine Dönüştü! }\end{array}$ & 21 Şubat 2021 & 3.3449 .657 & 39.412 & 7649 \\
\hline $\begin{array}{l}\text { Ecrin Su } \\
\text { Çoban }\end{array}$ & $\begin{array}{l}\text { YER MISİN? İÇER MİSİN? } \\
\text { Puding Benim Şarkımsa, } \\
\text { Milkshake Benim Dansım! }\end{array}$ & 26 Mayıs 2018 & 292.199 & 4987 & 681 \\
\hline $\begin{array}{l}\text { Prenses } \\
\text { Yankı }\end{array}$ & $\begin{array}{l}\text { Yankı ile Çocuk Oyunlarından } \\
\text { Buz Kırma Oyunu Oynuyoruz } \\
1 \text { Çocuk Videosu } 1 \text { Prens Yankı }\end{array}$ & 12 Aralık 2018 & 5.202 .729 & - & - \\
\hline
\end{tabular}

\footnotetext{
${ }^{1}$ Çocuk YouTuberların isimleri abone sayılarına göre düzenlenmiştir.
} 


\subsubsection{Oyuncak Avı Çocuk Kanalına İlişkin Bulgular}

“Oyuncak Avı” Kanalı, 29 Aralık 2014 yılında kurulmuştur. 7,676.625.851 görüntülenme sayısına sahip kanal, 15,2 milyon aboneye sahiptir. YouTube kanalında toplam 492 video vardır. "Oynatma Listelerinde" ise 27 adet Oynatma Listesi bulunmaktadır. "Kanallar" kısmında kanal bulunmamaktadır. Profilin "Hakkında" kısmında ise herhangi bir açıklama bulunmamaktadır (https://www.youtube.com/c/OyuncakAviTV/videos, 2014).

Profilde, kapak fotoğrafinda yıldızlar, gökkuşağı ve balon desenlerinin olduğu bir photoshop çalışmasının içinde kanalın adı ve kanalın karakteri Öykü bulunmaktadır. Profil fotoğrafı ise kelebek kanatları olarak Öykü'nün fotoğrafıdır. Oyuncak Av1 YouTube kanalında, babasıyla birlikte yapmış olduğu evcilik oyuncaları, öğretici oyunların olduğu video içerikler bulunmaktadır. Video kapaklarında, video konusuyla alakalı bir görsel bulunmakla birlikte, video başlığında çoğu zaman İngilizce ve Türkçe dikkat çekici başlıklar bulunmaktadır.

\section{Video 1. ÖYKÜ NUM NOMS TUTKUSU Learn Colors With Me and Watch Num Noms - Play Time}

Video 1'de “Oyuncak Avı” kanalının karakteri Öykü, renkli oyuncakları tanıtırken, birden Num Noms oyuncaklarıyla karşılaşır ve oyuncakları tanıtarak kutusundan çıkartır (https://www.youtube.com/watch?v=OEfJJhol_2s, 2018).

"ÖYKÜ NUM NOMS TUTKUSU learn colors with me and watch num noms - Play Time" isimli videonun çözümlemesi, çocukların ürettiği içerikler açısında nitel ve göstergebilimsel olarak aşağıda çözümlenmiştir

Tablo 3. "ÖYKÜ NUM NOMS TUTKUSU Learn Colors With Me and Watch Num Noms Play Time" Cözümlemesi

\begin{tabular}{|c|l|}
\hline Ana Tema & $\begin{array}{l}\text { Öykü bulduğu Num Noms oyuncaklarının kutusundan çıkartmakta ve teker teker } \\
\text { tanıtmaktadır. }\end{array}$ \\
\hline Video Uzunluğu & $\begin{array}{l}249 \text { saniye } \\
(4: 09)\end{array}$ \\
\hline Marka & Num Noms \\
\hline Karakterler & Öykü \\
\hline Kurgu & $\begin{array}{l}\text { Çoklu çekim kullanılmıştır. Geçiş efektleri yumuşaktır. Yoğun olarak dijital efektler } \\
\text { kullanılmıstır. }\end{array}$ \\
\hline Ses & Videoda sadece Öykü konuşmaktadır. Arka planda müzik vardır. \\
\hline $\begin{array}{c}\text { Tekrarlanan } \\
\text { İfadeler }\end{array}$ & $\begin{array}{l}\text { "Num Noms değil mi bunlar? Hemen bunları alayım" } \\
\text { "Sonunda Türkiye'ye bunlarda geldi ya”, "Bu bir dudak kremi, dudağınız çatladığını } \\
\text { kullanabilirsiniz. Num nomslar bunun için çok gerekli" }\end{array}$ \\
\hline
\end{tabular}

Tablo 3'te, "ÖYKÜ NUM NOMS TUTKUSU learn colors with me and watch num noms Play Time" Çözümlemesi bulunmaktadır.

Tablo 4. "ÖYKÜ NUM NOMS TUTKUSU Learn Colors With Me and Watch Num Noms Play Time” Göstergebilimsel Analizi

\begin{tabular}{|c|c|c|c|}
\hline Biçim & İçerik & Düzanlam & Reklam \\
\hline \multirow{3}{*}{$\begin{array}{c}\text { Öykü’nün renkleri } \\
\text { tanıtırken oyuncak } \\
\text { kutularıyla karşılaşması }\end{array}$} & \multirow{3}{*}{$\begin{array}{l}\text { Öykü'nün Num Noms } \\
\text { oyuncaklarıla birlikte } \\
\text { karşılaşması ve oyuncakları } \\
\text { teker teker tanıtması }\end{array}$} & $\begin{array}{c}\text { Öykü bulduğu oyuncakları } \\
\text { teker teker tanıtıyor }\end{array}$ & \multirow{3}{*}{$\begin{array}{c}\text { Video } 1 \text { içeriğinde } \\
\text { Öykü'nün Num Noms } \\
\text { markasına ait oyuncak } \\
\text { bebekler için kullandığı } \\
\text { ifadeler neticesinde, } \\
\text { videoyu izleyen çocuklar bu } \\
\text { oyuncağı satın almak } \\
\text { isteyeceklerdir. }\end{array}$} \\
\hline & & Yananlam & \\
\hline & & $\begin{array}{c}\text { Num Noms markasına ait } \\
\text { oyuncak bebeklerin oldukça } \\
\text { güzel kokması ve çok şirin } \\
\text { olması }\end{array}$ & \\
\hline
\end{tabular}


"Oyuncak Avı" YouTube profilinin analizi doğrultusunda elde edilen bulgulara göre ise; Öykü, annesi ve babasıyla birlikte oyuncak ve eğitici videolar çekildiği görülmektedir. Çekilen videoları geneli yarı profesyoneldir. Profesyonel olarak video kurgu ve ses efekti olan videolarda, video içeriği belli bir hikâye üzerine oturtulmuştur. Videoda reklam kullanımı bilinçli bir şekilde ürün yerleştirme ve sponsorlu içerik olarak yapılmıştır. Videolarda kullanılan üslup önceden hazırlanmış ve yarı doğaçlama olarak belirli bir planda gerçekleşmiştir. Kanal ebeveynlerinin denetiminde profesyonel olarak yönetilmektedir. Video başlıkları genellikle İngilizcedir ve basitçe video içeriği ile ilgili bilgi verilmektedir.

\subsubsection{Vlad ve Nikita Çocuk Kanalına İlişkin Bulgular}

"Vlad ve Nikita" Kanalı, 11 Mart 2019 yılında kurulmuştur. 799.951.091 görüntülenme sayısına sahip kanal, 1,89 milyon aboneye sahiptir. YouTube kanalında toplam 266 video vardir. "Oynatma Listelerinde" ise 1 adet Oynatma Listesi bulunmaktadır. "Kanallar" kismında ise 68.7 Milyon aboneye sahip "Vlad and Niki" kanalı bulunmaktadır. Profilin "Hakkında" kısmında ise "Vlad \& Niki Dükkanı: https://vladandniki.com/." açıklaması bulunmaktadır (https://www.youtube.com/channel/UCsZoAGyfzP1v5Z2BWyDU1kA/videos, 2019).

Profilde, bir photoshop çalışmasının içinde kanalın adı ve kanalın karakterleri Vlad ve Nikita'nın fotoğrafı bulunmaktadır. Profil fotoğrafı ise fotoğraf olarak Vlad'ın fotoğrafıdır. Vlad ve Nikita YouTube kanalında, çoğu zaman annesiyle birlikte oyuncak videoları ve kendi ürettikleri oyunların bulunduğu içerikler üretmektedir. Video kapaklarında, video konusuyla alakalı bir görsel bulunmakla birlikte, video başlığında ise video içeriğiyle ilgili bilgi vermektedir. Kanal, "Vlad ve Niki" isimli kanalın, Türkiye için açılmış olan bir kanalıdır. Video içerikler, Türkçe dublaj olarak yayınlanmaktadır.

\section{Video 2. Vlad ve Niki Oyuncak Kamyonlarla Eğleniyor | Hot Wheels Canavar Kamyonlar}

Video 2'de "Vlad ve Nikita" kanalının karakteri Vlad ve Niki, kendilerine gelen Hot Wheels oyuncağıyla birlikte oynamaktadırlar (https://www.youtube.com/watch?v=fQiyOc9KlTA, 2021).

"Vlad ve Niki Oyuncak kamyonlarla eğleniyor | Hot Wheels Canavar Kamyonlar" isimli videonun çözümlemesi, çocukların ürettiği içerikler açısında nitel ve göstergebilimsel olarak aşağıda çözümlenmiştir.

Tablo 5. "Vlad ve Niki Oyuncak Kamyonlarla Eğleniyor | Hot Wheels Canavar Kamyonlar" Çözümlemesi

\begin{tabular}{|c|l|}
\hline Ana Tema & Vlad ve Nikita'nın Anneleriyle birlikte oyuncak arabalarıyla oynaması \\
\hline Video Uzunluğu & $\begin{array}{l}356 \text { saniye } \\
(5: 56)\end{array}$ \\
\hline Marka & "Hot Wheels" markasına ait "Canavar Kamyonlar" oyuncağ1 \\
\hline Karakterler & Vlad, Nikita ve Anne \\
\hline Kurgu & $\begin{array}{l}\text { Videoda birden fazla kamera ve birden fazla kurgu yöntemi kullanılmıştır. Dijital görsel } \\
\text { efektler oldukça fazladır. }\end{array}$ \\
\hline Ses & $\begin{array}{l}\text { Vlad,Nikita ve Anneleri konuşmaktadır. Ses Türkçe dublajdır. Profesyonel olarak } \\
\text { seslendirilmiştir. Arka planda müzik ve ses efektleri vardır. }\end{array}$ \\
\hline $\begin{array}{c}\text { Tekrarlanan } \\
\text { İfadeler }\end{array}$ & $\begin{array}{c}\text { "Hadi Monster Trucks oynayalım", "Anne ben Hot Wheels Monster Trucks istiyorum", } \\
\text { "Büyük oyna, Hot Wheels", "Daha fazla Monster Trucks, daha fazla eğlence". }\end{array}$ \\
\hline
\end{tabular}

Tablo 5'te, "Vlad ve Niki Oyuncak kamyonlarla eğleniyor | Hot Wheels Canavar Kamyonlar" Çözümlemesi bulunmaktadır. 
Tablo 6. "Vlad ve Niki Oyuncak Kamyonlarla Eğleniyor | Hot Wheels Canavar Kamyonlar" Göstergebilimsel Analizi

\begin{tabular}{|c|c|c|c|}
\hline Biçim & İçerik & Düzanlam & Reklam \\
\hline & & $\begin{array}{c}\text { Vlad ve Nikita Hot } \\
\text { Wheels oyuncaklarıyla } \\
\text { oynarken eğleniyorlar. } \\
\text { Yananlam }\end{array}$ & \multirow{2}{*}{$\begin{array}{l}\text { Video } 2 \text { içeriğinde Vlad } \\
\text { ve Nikita'nın "Hot } \\
\text { Wheels" markasın ait } \\
\text { ürünlere yönelik } \\
\text { kullandıkları ifadeler } \\
\text { neticesinde, videoyu } \\
\text { izleyen çocuklar Hot } \\
\text { Wheels oyuncak } \\
\text { arabalarıyla oynamak ve } \\
\text { satın almak } \\
\text { isteyebileceklerdir. }\end{array}$} \\
\hline $\begin{array}{l}\text { Vlad ve Nikita'nın Araba } \\
\text { oyuncaklarıyla oynamas1 }\end{array}$ & $\begin{array}{l}\text { Vlad ve Nikita'nın Hot } \\
\text { Wheels oyuncaklarıyla } \\
\text { birlikte oynaması }\end{array}$ & $\begin{array}{c}\text { "Hot Wheels" oyuncak } \\
\text { arabaları oldukça } \\
\text { eğlenceli }\end{array}$ & \\
\hline
\end{tabular}

"Vlad ve Nikita" YouTube profilinin analizi doğrultusunda elde edilen bulgulara göre ise Vlad ve Nikita uluslararası 68.7 milyon aboneye sahip olan bir kanalın yan kanalıdır. Ana kanalın dili Rusça olmakla birlikte, bu kanallar; Arapça, İngilizce, Türkçe ve İspanyolca olarak seslendirilen diğer kanallara sahiptir. Kanallarda her detay tamamen profesyoneldir. Video açıları ve kurgusu profesyonel set ekibiyle yapılmıştır. Videolarda dijital efekt ve ses efektleri oldukça yoğun kullanılmıştır. Çocuklar ise içeriklerini profesyonel olarak tanıtmaktadır. Reklam içerikleri sponsorluk içeriklerdir. Profesyonel ve YouTube Reklam standartlarına uygundur. Video içerisinde ürünün reklam olduğu her seferinde belirtilmiştir. Video başlıklarında yayınlanan kanalın diline göre video içeriği ile ilgili bilgi verilmektedir. Video görsellerinde ise profesyonel olarak dikkat çekici görseller kullanılmaktadır.

\subsubsection{Prenses Lina TV Kanalına İlişkin Bulgular}

"Prenses Lina TV" Kanalı, 6 Ağustos 2017 y1lında kurulmuştur. 1,580.091.132 görüntülenme sayısına sahip kanal, 1,88 milyon aboneye sahiptir. YouTube kanalında toplam 458 video vardır. "Oynatma Listelerinde" ise 19 adet Oynatma Listesi bulunmaktadır. "Kanallar" kısmında kanal bulunmamaktadır. Profilin "Hakkında" kısmında ise "Merhaba ben Lina; AILECEK GEÇIRDİĞIMİZ GÜZEL VAKITTLERI SIZINLE PAYLAŞMAK IÇIN KURDUĞUMUZ KANALIMIZA HEPINIZZ DAVETLISINIIZ. Videolarımı izledikten sonra yorumlarınızı yazıp beğenirseniz ve kanalıma abone olursanız çok sevinirim. Sizinle her gün yeni videolar paylaşmaya çalışacağım. Kendinize iyi bakın. Sizi çoook seviyoruz." açıklaması ve açıklamanın İngilizcesi bulunmaktadır (https://www.youtube.com/c/PrensesLinaTv/videos, 2017).

Profilde, kapak fotoğrafında bir bahçenin içerisinde Pamuk Prenses karakterinin bulunduğu photoshop çalışmasının içinde kanalın adı ve kanalın karakteri Lina'nın iki fotoğrafi bulunmaktadır. Profil fotoğrafı yine aynı fotoğraf olarak Lina'nın fotoğrafıdır. Prenses Lina TV YouTube kanalında, çoğu zaman annesiyle olmak üzere, babasıyla birlikte tatil videoları, yemek tarifleri, kutlama videoları ve alışveriş videolarının bulunduğu içerikler üretmektedir. Video kapaklarında, video konusuyla alakalı bir görsel bulunmakla birlikte, video başlığında ise video içeriğiyle ilgili bilgi vermektedir.

\section{Video 3. Danone Mix Yiyen Lina'nın Elbisesi Frozen Elsa Kostümlerine Dönüştü!}

Video 3 'te "Prenses Lina TV" kanalının karakteri Lina, annesi ve babasıyla birlikte Danone markasının ürünlerini denemekte ve oynamaktadır (https://www.youtube.com/watch?v=oR5XcTGOJZA, 2021). 
“Danone Mix Yiyen Lina'nın Elbisesi Frozen Elsa Kostümlerine Dönüştü!” isimli videonun çözümlemesi, çocukların ürettiği içerikler açısında nitel ve göstergebilimsel olarak aşağıda çözümlenmiştir.

Tablo 7. “Danone Mix Yiyen Lina'nın Elbisesi Frozen Elsa Kostümlerine Dönüştü!” Çözümlemesi

\begin{tabular}{|c|c|}
\hline Ana Tema & Lina'nın annesiyle birlikte Danone ürünlerini incelemesi \\
\hline Video Uzunluğu & $\begin{array}{l}515 \text { saniye } \\
(8: 35)\end{array}$ \\
\hline Marka & $\begin{array}{l}\text { "Danone" markasına ait "Danone Hüpper" "Danone Mix" "Danone Çıtırdat" "Danone Milkshake" } \\
\text { ürünleri }\end{array}$ \\
\hline Karakterler & Lina, Annesi, Babas1 \\
\hline Kurgu & Çoklu çekim kullanılmıştır. Geçiş efektleri. Yoğun olarak geçiş efekti kullanılmıştır. \\
\hline Ses & Lina, annesi ve babası oyun oynarken çeşitli ses efekti ve müzik kullanılmıştır. \\
\hline $\begin{array}{c}\text { Tekrarlanan } \\
\text { İfadeler }\end{array}$ & $\begin{array}{l}\text { "Danone, Danone Mix yoğurtlarım var, Danoneci geldi çocuklar.", "Danone'den havalı lezzet } \\
\text { Milkshake var.", "Süper çocuklar için Danone Hüpper var. Şeker kaplı mısır gevreğini içine } \\
\text { karıştırabileceğin Danone Mix var. Çikolatalı ve Vanilyalı çıtır topları yoğurdun içine karıştırıp } \\
\text { yiyebileceğin eğlenceli bir Danone Çıtırdat var.", "Süper Çocuklar Danone Milkshake içer!", } \\
\text { "Danone Milkshake içerek Frozen Elsa ya dönüşütm". }\end{array}$ \\
\hline
\end{tabular}

Tablo 7'de, "Danone Mix Yiyen Lina'nın Elbisesi Frozen Elsa Kostümlerine Dönüştü!” Çözümlemesi bulunmaktadır.

Tablo 8: “Danone Mix Yiyen Lina'nın Elbisesi Frozen Elsa Kostümlerine Dönüștü!” Göstergebilimsel Analizi

\begin{tabular}{|c|c|c|c|}
\hline Biçim & İçerik & Düzanlam & Reklam \\
\hline \multirow{3}{*}{$\begin{array}{c}\text { Lina'nın } \\
\text { annesinin Danone } \\
\text { ürünlerini satması } \\
\text { ve Lina'nın } \\
\text { bunları yemesi }\end{array}$} & \multirow{3}{*}{$\begin{array}{l}\text { Lina yediği her } \\
\text { Danone ürünününde } \\
\text { bir karakter } \\
\text { kostümünü giyiyor. }\end{array}$} & $\begin{array}{c}\text { Lina'nın Danone ürünlerini } \\
\text { yedikten sonra, paket } \\
\text { üstündeki karakterin } \\
\text { kostümünü giyinmesi }\end{array}$ & \multirow{3}{*}{$\begin{array}{l}\text { Video } 3 \text { içeriğinde Lina, annesi ve } \\
\text { babasının "Danone" markasın ait } \\
\text { ürünlere yönelik kullandıkları } \\
\text { ifadeler neticesinde, videoyu } \\
\text { izleyen çocuklar Danone } \\
\text { ürünlerinin çok lezzetli ve eğlenceli } \\
\text { olduğunu düşünerek, bir masal } \\
\text { karakterine dönüşebilecekleri } \\
\text { düşüncesiyle ürünleri satın almak } \\
\text { isteyebileceklerdir. } \\
\text { Başlık ise bu durumda markanın ve } \\
\text { ürünün adın belirtmektedir. }\end{array}$} \\
\hline & & Yananlam & \\
\hline & & $\begin{array}{c}\text { "Danone" 'nin lezzetli } \\
\text { ürünlerini tüketen çocukların, } \\
\text { masal karakterlerine } \\
\text { dönüşecekler, Danone } \\
\text { yedikçe Prenses gibi } \\
\text { hissedeceklerini ve çok } \\
\text { eğlenecekleri. }\end{array}$ & \\
\hline
\end{tabular}

"Prenses Lina TV" YouTube profilinin analizi doğrultusunda elde edilen bulgulara göre ise Prenses Lina TV kanalının profil sahibi olan çocuk Lina'nın sosyal medyada ürettiği reklam içerikleri, tamamen ebeveynlerinin yönlendirmesiyle üretilmiştir. Video başlığında, video içeriği hakkında bilgi verilmiş, izleyicilere video içerisinde gizem uyandırması için konu yarım bırakılmıştır. Video içeriklerinde reklam unsuru olarak kabul edilen içeriklere ise, yer verilmiştir. Bunun yanı sıra, video içerisinde kullanılan üslup ve üretilen içerikler, izleyici çocuk kitlenin üzerinde olumsuz etki yaratabilecek videolar olabilmesidir. Videoların geneli incelendiğinde, Lina devamlı annesi tarafından yönlendirilmekte, doğaçlama olarak yaptığı davranışlar vlog tarzında kameraya kaydedilmekte ve tepkilerinin birleştirilmesiyle içerikler üretilmektedir.

\subsubsection{Ecrin Su Çoban Çocuk Kanalına İlişsin Bulgular}

"Ecrin Su Çoban” Kanalı, 4 Ocak 2016 y1lında kurulmuştur. 725.630.780 görüntülenme sayısına sahip kanal, 1,66 milyon aboneye sahiptir. YouTube kanalında toplam 594 video vardır. "Oynatma Listelerinde" ise 30 adet Oynatma Listesi bulunmaktadır. "Kanallar" kısmında "Ecrin Su Çoban'ın Oyuncak Dünyası", "ENBALIM" ve "HÜSO" adında üç kanal vardır. Profilin "Hakkında" kısmında ise, " $\$ SELAM. Kanalımda Eğlenceli Ve Kaliteli Videolar Bulacaksınız. AYRICA ecrin su çoban'ın oyuncak dünyası isimli 2. bir kanalım var." açıklaması bulunmaktadır (https://www.youtube.com/c/ecrinsucoban/videos, 2016). 
Kanalın kapak fotoğrafinda "Ecrin Su Çoban" profilindeki çocuk olan Ecrin Su Çoban'ın, parmaklarında isminin ve soyisminin baş harflerinin yazılı olduğu bir fotoğraf bulunmaktadır. Profil fotoğrafi ise yine kendi fotoğrafıdır. Ecrin Su Çoban YouTube kanalında, devamlı müzik, alışveriş ve vlog içerikleri bulunmaktadır. Video kapaklarında, video konusuyla alakalı bir kapak ve video başlığında ise ilgi uyandırıcı başlıklar bulunmaktadır.

\section{Video 4. YER Mísín? İÇER Mísín? | Puding Benim Şarkımsa, Milkshake Benim Dansım!}

Video 4'de, "Ecrin Su Çoban" kanalının karakteri Ecrin Su Çoban, Sponsorluk aldığı bir markanın Puding ve Milkshake ürünlerini yaparak tanıtmaktadır. Yapım sonrasında ise, ürünleri deneyerek hem deneyimlerini paylaşmakta hem de ürünü tanitmaktadir (https://www.youtube.com/watch?v=TAjM7HKHHdE, 2018).

"YER MİSIN? İÇER MİSİN? | Puding Benim Şarkımsa, Milkshake Benim Dansım!" isimli videonun çözümlemesi, çocukların ürettiği içerikler açısında nitel ve göstergebilimsel olarak aşağıda çözümlenmiştir.

Tablo 9. "YER MISIIN? ICÇER MİSiN? | Puding Benim Şarkımsa, Milkshake Benim Dansım!" Cözümlemesi

\begin{tabular}{|c|l|}
\hline Ana Tema & Ecrin Su Çoban'ın Puding ve Milkshake yapması \\
\hline Video Uzunluğu & $\begin{array}{l}\text { 251 saniye } \\
(4: 11)\end{array}$ \\
\hline Marka & Ülker Bizim Mutfak Express Puding \& Milkshake \\
\hline Karakterler & Ecrin Su Çoban \\
\hline Kurgu & Çoklu çekim \\
\hline \multirow{2}{*}{ Ses } & $\begin{array}{l}\text { Tek kişi konuşuyor. } \\
\text { Dijital efekt yok. } \\
\text { Müzik var. }\end{array}$ \\
\hline $\begin{array}{c}\text { Tekrarlanan } \\
\text { İadeler }\end{array}$ & $\begin{array}{l}\text { "Bizim Mutfağın çıkardığı Milkshake ve pudingi yapacağı." } \\
\text { "Bunun en önemli özelliği hem puding hem de milkshake olması." }\end{array}$ \\
\hline
\end{tabular}

Tablo 9'da, "YER MISİN? IÇER MISINN? | Puding Benim Şarkımsa, Milkshake Benim Dansım!” çözümlemesi bulunmaktadır.

Tablo 10. "YER MisíN? İÇER MísíN? | Puding Benim Şarkımsa, Milkshake Benim Dansım!" Göstergebilimsel Analizi

\begin{tabular}{|c|c|c|c|}
\hline Biçim & İçerik & Düzanlam & Reklam \\
\hline \multirow[b]{3}{*}{$\begin{array}{l}\text { Puding ve Milkshake } \\
\text { yapan bir kız çocuğu }\end{array}$} & \multirow[b]{3}{*}{$\begin{array}{l}\text { Puding ve Milkshake } \\
\text { yapan ve deneyimini } \\
\text { paylaşan bir kız çocuğu }\end{array}$} & $\begin{array}{l}\text { Ecrin Su Çoban'ın Puding } \\
\text { ve Milkshake yapması }\end{array}$ & \multirow{3}{*}{$\begin{array}{l}\text { Video } 4 \text { içeriğinde Ecrin } \\
\text { Su Çoban'ın "Puding \& } \\
\text { Milkshake" için kullandığı } \\
\text { ifadeler neticesinde, } \\
\text { videoyu izleyen çocuklar } \\
\text { Ülker Bizim Mutfak } \\
\text { markasına ait "Express } \\
\text { Puding \& Milkshake" in } \\
\text { lezzetli olduğu sonuca } \\
\text { varacak ve satın almak } \\
\text { isteyeceklerdir. }\end{array}$} \\
\hline & & Yananlam & \\
\hline & & $\begin{array}{c}\text { Ülker Bizim Mutfak } \\
\text { markasına ait "Express } \\
\text { Puding \& Milkshake” ‘in } \\
\text { çok kolay ve hızlı } \\
\text { yapılması, ayrıca çok } \\
\text { lezzetli olması. }\end{array}$ & \\
\hline
\end{tabular}

"Ecrin Su Çoban" YouTube profilinin analizi doğrultusunda elde edilen bulgulara göre ise Ecrin Su Çoban, çeşitli müzik yarışmalarından sonra elde ettiği şöhreti sosyal medyada ürettiği içeriklerle devam ettirmektedir. Videolarının genel içeriği hep vloglardan oluşturmaktadır. Günlük hayatının detaylarını paylaştığı bu vlogların içerisinde yoğun olarak "Alışveriş" vlogları bulunmakta ve bu vloglarda devamlı markalardan alışveriş yaparak olumlu yorumlarda bulunmaktadır. Videolarında sadece kendisi konuşmamaktadır ve başka bir karakter bulunmamaktadır. Bazı videolarında farklı kişileri konuk etmektedir. 
Videoları basit kurgu olmakla birlikte, reklam içerikli videoları profesyonel kurguyla yapılmıştır. Video başlıklarında video içeriği ile ilgili bilgi verilmektedir. Aynı zamanda video başlığ 1 , video görselinde de bulunmaktadır.

\subsubsection{Prens Yankı Çocuk Kanalına İlişkin Bulgular}

"Prens Yankı" Kanalı, 21 Ağustos 2015 yılında kurulmuştur. 643.440.273 görüntülenme sayısına sahip kanal, 1,29 milyon aboneye sahiptir. YouTube kanalında toplam 636 video vardır. "Oynatma Listelerinde" ise 16 adet Oynatma Listesi bulunmaktadır. "Kanallar" kısmında "Rüya'nın Çiftliği”" ve "Oziko" adında iki kanal vardır. Profilin "Hakkında" kısmında ise, "Merhabalar efendim. Prens Yankı kanalına hoş geldiniz. 5 yıldır Youtube'da içerik üreten bir baba olarak bu kanalda oğlum Yankı ve Eşim Selma ile birlikte eğlenceli videolar çekiyoruz. Videolarımızın tamamı anne ve baba filtresinden geçmektedir. İçeriklerimiz ailece izleyebileyeceğiniz türden. Nitekim sizlerden aldığımız geri dönüşlerde de bunu görmekteyiz. Hepinize teşekkür ederiz. Baba yada Anne iseniz içiniz rahat olabilir. Yankl, ben ve Selma ile birlikte eğlenceli, komik ve bir o kadar eğitici ögretici videolara hazır mısınız ? O zaman gülmeyi unutmayın! Bu kanal, Yankı Kosif'in ailesi tarafindan oluşturulmuştur ve sürekli olarak ailenin denetimi altındadır. Video içeriklerinde asla gençleri olumsuz etkileyecek davranışlar yer almaz. Bu kanal CK Dijital Tarafindan Yönetilmektedir." açılklaması bulunmaktadır (https://www.youtube.com/c/Kosifler/videos, 2015).

Kanalın kapak fotoğrafinda "Prens Yankı" profilindeki çocuk olan Yankı, Annesi ve Babasının birlikte olduğu bir photoshop çalışması yapılmıştır. Profil fotoğrafi ise kapak fotoğrafiyla aynıdır. Prens Yankı YouTube kanalında, devamlı oyuncak tanıtım ve oyun videoları içerikleri bulunmaktadır. Video kapaklarında, video konusuyla alakalı bir kapak ve video başlığında ise ilgi uyandırıcı başlıklar bulunmaktadır.

\section{Video 5. Yankı ile Çocuk Oyunlarından Buz Kırma Oyunu Oynuyoruz -Çocuk Videosu- Prens Yankı}

Video 5'te, "Prens Yankı" kanalının karakteri Yankı, odasında oyuncaklarıyla oynarken annesi gelir. Yankı'nın sakladığı "Buz Kırma oyunu” kutusunu alırlar ve odada oyunu oynamaya başlarlar. Video süresince Annesi ve Yankı oyunu tanıtırlar (https://www.youtube.com/watch?v=RyeblEZrjaw, 2018).

"Yankı ile Çocuk Oyunlarından Buz Kırma Oyunu Oynuyoruz" isimli videonun çözümlemesi, çocukların ürettiği içerikler açısında nitel ve göstergebilimsel olarak aşağıda çözümlenmiştir.

Tablo 11. "Yankı ile Çocuk Oyunlarından Buz Kırma Oyunu Oynuyoruz" Çözümlemesi

\begin{tabular}{|c|l|}
\hline Ana Tema & Buz Kirma Oyununun oynanması \\
\hline Video Uzunluğu & $\begin{array}{l}871 \text { saniye } \\
(14: 31)\end{array}$ \\
\hline Marka & Hasbro Gaming Buzu Kırma \\
\hline Karakterler & Yankı ve Annesi \\
\hline Kurgu & Tek çekim \\
\hline Ses & $\begin{array}{l}\text { Diyalog var. } \\
\text { Dijital efekt yok. }\end{array}$ \\
\hline $\begin{array}{c}\text { Tekrarlanan } \\
\text { Ifadeler }\end{array}$ & $\begin{array}{l}\text { "Biz bu oyunu çok seviyoruz ve hep oynuyoruz. } \\
\text { "Buz Kirma Oyunu” }\end{array}$ \\
\hline
\end{tabular}

Tablo 9'da "YER MISINN? IÇER MISINN? | Puding Benim Şarkımsa, Milkshake

Benim Dansım!” Çözümlemesi bulunmaktadır. 
Tablo 12. "Yankı ile Çocuk Oyunlarından Buz Kırma Oyunu Oynuyoruz" Göstergebilimsel Analizi

\begin{tabular}{|c|c|c|c|}
\hline \multirow{2}{*}{ Biçim } & İçerik & Düzanlam & Reklam \\
\hline \multirow{2}{*}{$\begin{array}{c}\text { Çocuk Kutu } \\
\text { oyununu oynayan } \\
\text { anne ve oğlu }\end{array}$} & $\begin{array}{c}\text { Tesadüfi bir şekilde, Çocuk } \\
\text { Kutu oyununu oynayan } \\
\text { anne ve oğlu }\end{array}$ & $\begin{array}{c}\text { Yank1 ve annesinin "Buzu } \\
\text { Kırma" Kutu oyununu } \\
\text { oynamas1 }\end{array}$ & $\begin{array}{c}\text { Video 5 içeriğinde Yank1 } \\
\text { ve annesinin "Buzu Kırma" } \\
\text { Çocuk Kutu oyunu için } \\
\text { kullandiklar1 ifadeler } \\
\text { neticesinde, videoyu }\end{array}$ \\
\cline { 3 - 3 } & $\begin{array}{c}\text { Yananlam } \\
\text { izleyen çocuklar Hasbro } \\
\text { markasina ait "Gaming } \\
\text { Buzu Kirma" çocuk kutu } \\
\text { oyunu tercih etmek } \\
\text { isteyeceklerdir. }\end{array}$ \\
\hline
\end{tabular}

"Prens Yank1" YouTube profilinin analizi doğrultusunda elde edilen bulgulara göre ise Prens Yankı kanalının profil sahibi olan çocuk Yankı'nın belirlenen reklam içeriklerinin tamamında, içerikler genellikle ebeveynlerinin yönlendirmesiyle üretilmiş olmakla birlikte, Yankı ürün tanıtımında sadece yardımcı roldedir. Video başlığında, video içeriği hakkında bilgi verilmiş, izleyiciler video içerisinde gizem uyandıracak herhangi bir şeye rastlamamıştır. Yankı özellikle annesiyle birlikte, çeşitli videoları vlog şeklinde çekmektedir. Videoların geneli incelendiğinde, annesiyle beraber oynadığı ve oyuncak kutu açılımları yaptığı videolar paylaşılmıştır. Videolarda kullanılan üslup genellikle doğaçlama olmakla birlikte, bazı durumlarda ebeveyn müdahalesi bulunmaktadır. Video çekimleri amatör ve tek parçadır. Basit kurgu kullanılmıştır. Video başlıklarında video içeriği ile ilgili bilgi verilmektedir. Video görsellerinde ise profesyonel olarak dikkat çekici görseller kullanılmaktadır.

\section{Sonuç ve Öneriler}

Sosyal ağların ulaşılabilirliğinin kolaylaşması ve sosyal medya kullanımının artması, her kullanıcıya birer "Dijital Kimliğe" sahip olma olanağı vermiştir. Gelişimini tüm hızıyla sürdüren sosyal medya ise yeni medya ağlarıyla kendini yenilerken, üreten tüketiciler kendi içeriklerini üretmekte, bir o kadar da içerik tüketmektedirler. Sosyal medyada kullanıcıların ürettiği bu içerikler, çoğu zaman içerik pazarlaması olarak da sunulabilmektedir. Web 2.0'ın hayatımıza girmesiyle birlikte kendi içeriklerini üretmeye başlayan kullanıcılar hem üretici hem de tüketici haline gelmiş, birer "Prosumer" yani üreten tüketici olmuşlardır. Son 15-20 yıl içerisinde internetin gelişmesi, üreticiler için bir fırsat, tüketiciler içinse bir endişe haline gelmiş görülmektedir.

Sosyal medyada içeriklerin üretilmesiyle birlikte, tüketicilerin talepleri oluşmuş, içerik üreticileri bu talebe göre içerik üretmeye başlamışlardır. Her yaşa ve kesime hitap eden üreticilerin bir kısmı özellikle sosyal medyada çocuk tüketicileri hedef kitle olarak baz almış, çocuklara göre içerik üretmeye yönelmiştir. Bu durumda, henüz küçük yaşta "YouTuber"lı̆̆ meslek olarak görmeye başlayan çocuklar, sosyal medyada maruz kaldıkları içerikler doğrultusunda, kendi içeriklerini üretmek isteyebilmektedirler. Çocukların bu taleplerini, kendi yararları için değerlendirmek isteyen ebeveynler ise, çocukların içeriklerini üretmelerine destek vermiş, çoğu zaman etkileşimi arttırmak adına video içeriklerini yönlendirmişler.

Sosyal medyada yayınlanan bu içerikler, reklam olarak kullanımın artmasıyla birlikte, markaların ilgi odağı haline gelmiş, ürün tanıtımlarını video içeriklerinde doğrudan veya dolaylı yoldan tanıtılabilmesine olanak vermiştir. Ürün tanıtımlarını, video içeriklerinin izleyici kitlesine göre hazırlayan markalar, böylece hedef kitlesini daha belirgin olarak görebilmişlerdir. 
Geleneksel medyadaki çocuk kanalları; çizgi film, çocuk programlarında reklam arasında reklam verirken, günümüzde sosyal medyada, içeriklerin arasında reklam yerine, artık içeriklerin içerisinde reklamlar kullanılmaya başlanmıştır. Söz konusu çocuklar olduğunda, markaların hedef kitlesi olan çocuklara ulaşmasını oldukça kolaylaştırmıştır. $\mathrm{Bu}$ durum çocuk hedef kitlesine ulaşmak isteyen markalar için, çocuk içerik üreticisini oldukça önemli kılmıştır.

"Sosyal Medya Etkileyicileri” olarak tanımlanan “influencer"lar için ise bir takım yasal düzenlemeler yapılmış, bu düzenlemelerde çocukların sosyal medyada ürettikleri içeriklere yer verilmemiştir. Yapılan ihlallerde caydırıcı bir yaptırım ve yeterli denetim mekanizması olmadığından yetersiz kalmıştır. Çocuk YouTuberlar ürettikleri reklam içeriklerin tamamında reklam olduğunu belirten açıklamalar bulunmamaktadır. Bu durumda yapılan yasal düzenlemeler, çocukların ürettikleri içeriklerin denetlenmesi durumunda eksik kalmış, çocukların bir reklam işçisi olarak kullanımının önüne geçememiştir.

Sonuç olarak, çocuk kullanıcıların sosyal medya ürettiği reklam içeriklerinin, özellikle hedef kitle çocuklara yönelik olduğu ve cinsiyet fark etmeksizin oyuncakların incelendiği gözlenmiştir. K1z çocuk içerik üreticilerinin, erkek çocuklara yönelik oyuncakları, erkek çocuk içerik üreticilerin ise; kız çocuklarına yönelik oyuncakları incelediği görülmüş̧ür. Bu durumda söz konusu çocuklar olduğunda, bir ücret veya ücretsiz ürün karşılığında üretilen reklam içeriklerin, çocuklar tarafindan oldukça fazla tercih edilebilir olduğu görülmektedir.

Ürünlerini tanıtmak için bir içerik üreticiyle iş birliği yapan markalar ise ürünlerini hedef kitlelere göre pazarlamayı tercih etmektedirler. Söz konusu hedef kitle özellikle çocuklar olduğunda, markalar tarafından yapılan iş birlikleri, çocuk içerik üreticilerle birlikte olmaktadır. Üretilen içerikler, genellikle ücretli tanıtım ve belli bir kurgu üzerine oturulmuş hikâye olarak Çocuk YouTuberlar tarafindan, çocuk takipçilerine sunulabilmektedir.

Çocuk YouTuberların ürettiği içeriklerin içeriğine bakıldığında ise, içeriğe çocuklar değil, genellikle ebeveynleri karar vermektedir. Çocuk kullanıcıların kişisel sosyal ağlarının, çocukların tamamen kontrolünde olmadığı, ebeveynlerinin denetiminde ve kontrolünde içerik üretimi yapıldığı görülmektedir. Gerek yaşları gerekse yasal hakları doğrultusunda bu markalarla iş birliğini, çocukların sosyal medya hesaplarını kontrol eden ebeveynler tarafından gerçekleştirilmektedir. Reklam içeriklerinde ise reklamların dolaylı yoldan veya doğrudan ürün yerleştirebildikleri ve üretilen içerikte reklamın başarılı bir şekilde izleyiciye ulaştığı sonucuna varılmaktadır.

Ebeveynin denetiminde üretilen içeriklerde, devamlı kamera karşısında olmak, çocuğun kişisel alanı içerisinde "vlog" tarzında üretilen içerikler çocukların mahremiyet algısını zedelemektedir. Markaların talepleri doğrultusunda belli bir senaryo üzerine üretilen reklam içerikler ise hem içeriği üreten çocuk kullanıcının hem de içeriği tüketen çocukların gerçeklik ile kurgu arasındaki farkı anlamasını zorlaştırmaktadır.

Markalar açısından değerlendirildiğinde, sosyal medyada içerik üreticilerin ürettiği reklam içerikler, pazarlama stratejisinde kullanılabilmektedir. Üretilen içeriklerin, hedef kitlesi net olduğundan markalar tarafından tercih edilebilir olmuştur. Tüketicilerin, izledikleri içeriklerde markayı görmeleri markalara yönelim bir güven veya sempati oluşturabilmektedir. Ücretli iş birliği veya sponsorluğun gerçekleştiği bu içerikler, markanın imajını olumlu derecede etkileyebilmektedir. 
Ürün tanıtımlarında çocukların markaya yönelik kullandıkları ifadelere bakıldığında ise, genellikle ebeveynler ve markalar tarafından yönlendirilen kalıplar kullanılmaktadır. Markaya ve ürüne yönelik kullanılan olumlu ifadeler bulunmaktadır. Kullanılan reklam metinleri ise çocukların hedef kitlesinin anlayabileceği düzeydedir. Doğaçlama bir şekilde yapılan tanıtımlarda ise genellikle ebeveynlerin marka hakkında olumlu ifadeleri yer almaktadır. Bu içeriklerde, çocuk sadece markayla bağdaştırılmış bir hedef kitle durumundadır. Ebeveynlerin ve markaların yönetiminde üretilen reklam içeriklerde Ebeveyn; reklamı yapan kişi, Marka; Reklamı yapılan ürün. Çocuk ise; Markanın hedef kitlesi rolündedir. $\mathrm{Bu}$ ise, çocukların bir reklam aracısı olarak kullanılmasının önünü açmaktadır. Bir başka ifadeyle ebeveynler ile markaların arasında iş birliği neticesinde, ebeveynler; çocuklarını ve yüksek aboneye sahip hedef kitlesini reklam olarak sunmaktadır. Bu durum, çocukların bir reklam yüzü olarak sosyal medyada paylaşılmasının önünü açmaktadır.

$\mathrm{Bu}$ çalışma, sosyal medyada çocukların ürettiği reklam içerikler konusunda çocukların ürettiği içeriklerde reklam kullanımının kontrol edilebilmesi amacıyla bazı öneriler sunmakta yarar vardır:

1. Çocuk içerik üreticilerinin, ürettikleri içerikler konusunda bilgilendirilmesi gerekmektedir.

2. Ebeveynlerinin kontrolünde üretilen içeriklerde, çocuğun mahremiyetini zedeleyecek içerikler üretilmemelidir.

3. Çocuk içerik üreticilerin sosyal medya hesaplarında, abonelerini olumsuz etkileyecek paylaşımlar yapılmamalıdır. Üretilen içerikler, içerik tüketenler içinde önemlidir.

4. Çocuk içerik üreticilerinin ürettiği içeriklerde ürün yerleşimi ve reklam kullanımı hedef kitleye uygun olmalı ve “..sponsorluğunda”, “...iş ortaklığıyla” veya \#reklam gibi üretilen içeriğin reklam olduğunu belirten açıklamalar kullanılmalıdır.

5. Çocukların sosyal medya kullanım alışkanlıkları ebeveynleri tarafindan kontrol altında tutulmalı, Sosyal medya bağımlılığının önüne geçilmelidir.

6. Ebeveynleri tarafindan çocuklara henüz küçük yaşta medya okuryazarlığı eğitimi verilmeli ebeveynler ise çocukları için doğru medya içeriğini ayırt edebilmek için medya okuryazarlığı eğitimi almalıdır.

7. Ebeveynler, çocuklarını içerik üretimi için zorlamamalı, çocuklarını reklam unsuru olarak kullanmamalıdırlar.

8. Çocukların sosyal medyada ürettiği içerikler denetlenmeli, çocuğun mahremiyetini ihlal edebilecek ve sağlığını etkileyebilecek içeriklere kısıtlama getirilmelidir.

9. Çıkartılacak olan yasalarda çocukların sosyal medya içeriklerinde reklam olarak kullanımını denetleyecek mekanizmalar geliştirilmeli, çocukların reklam olarak kullanımına sınırlılıklar getirilmelidir. Youtube Reklam Denetimi getirilmeli, çocuk içerik üreticilerle ilgili maddeler oluşturulmalıdır.

10. Markalar, ürettikleri içeriklerde çocukların sağlığı ve mahremiyetini göz önünde bulundurmalı, hedef kitleye uygun içeriklerle pazarlama stratejisini gerçekleştirmelidir. 


\section{Extended Abstract}

Although children in social media are a subject that has been studied extensively in the world and in our country in recent years, studies on Advertising Content Produced by Child Users in social media are very limited. With this study, firstly, a literature study was conducted on social media and the content created by users, and then a semiological and qualitative research was carried out on advertisements on social media and advertising content created by child users, by examining the contents produced by child YouTubers.

The aim of the study is to examine how child users are exposed to social media advertising in the content they produce and to analyze the advertisements within these contents. In this context, in the Conceptual Framework, which is the first part of the study, advertisements produced by users were created, content producers and content types in social networks were discussed, and Content Produced by Child Users and advertising contents were emphasized. In the second part of the study, a total of 5 videos of "Oyuncak Avl", "Vlad ve Nikita", "Prenses Lina Tv", "Ecrin Su Çoban", and "Prens Yankl" child YouTubers containing an advertisement element, a total of 5 videos, were analyzed semiotically and qualitatively. The findings were examined by content analysis method.

The conceptual framework of the study consists of content producers in social media, use of branded content in social media and content marketing, branded content and user generated branded content, as well as branded content created by child users. Content producers on social media; the types of content producers in social media, how content producers are classified in social media and which generations they are representatives of are explained. In the use of branded content in social media and content marketing; The birth of the idea of content marketing with the content produced by the brands on social media and the transition process of the produced content to content marketing are mentioned. Within the framework of branded content; The usage patterns of branded content and the definition of branded content marketing are mentioned. In user generated branded content; It is explained who created the content, the types of content and on which social networking platforms these contents were created. And finally, in the content created by Child users; The presentation of children on social media, how they become productive consumers, the legal regulations regarding the use of children as advertisements, the content produced by children on social media and the analysis of advertisements produced in these contents are included.

The aim of this study; to determine the content produced by child users who produce content in social media and to examine and evaluate the advertising usage activities in these contents. In other words, it is the basis of the study to analyze how and where children's content producers position the advertisement in their video content. In this context, by examining the advertisements in the content produced by children's YouTubers, it is aimed to understand how they use social media as an advertising tool at a young age and how the content they produce is advertisement-oriented.

The universe of the study consists of all children's video content producers on the social media platform YouTube. The sample of the study is random sampling. It is the video content produced by 5 Child YouTubers randomly selected among 25 Child YouTubers with 1 million or more subscribers. The contents include 1 video with a purposefully selected advertising element.

Semiotic analysis and qualitative content analysis technique were used as research methods in the study. According to Krippendorff, content analysis is a research technique used to draw reproducible and valid conclusions from data about its content (Krippendorff 1980, p.25 cited from Koçak \& Arun, 2006). Qualitative content Analysis, on the other 
hand, is a technique that requires organizing all comprehensive materials in order to analyze the messages in the sources related to human behavior and allows working on determining human nature and behaviors through indirect means (Büyüköztürk et al., 2008, p. 240). In the analysis of the video contents used in the study, Roland Barthes' denotation and connotations were discussed by using the concepts of content and form. Every object, content, image and message has different meanings. These phenomena include many different indicators from each other. It is easier to perceive the message that the content wants to convey when the subject and indicators are chosen correctly or when the indicators are properly interpreted (Barthes, 1986, p. 33-36 as cited in Öztürk, 2014, p. 88). Qualitative content analysis method is an accurate method to reveal the advertisement in the video content produced by Children, and Semiotic Analysis is a correct method to reveal the information about the use of the advertisement used in the produced content, the meanings attributed to the brand in the content and the image of the brand.

The limitations of the study were examined and limited by the semiotic analysis and qualitative content analysis techniques, in the use of advertisements in the video content produced by the "Child Users who produce Content on YouTube" YouTube accounts. It is the video content produced by 5 Children YouTubers, randomly selected from 25 child YouTuber accounts with 1 million subscribers. In this context, the contents are; "Oyuncak Avı", "Vlad ve Nikita", "Prenses Lina Tv", "Ecrin Su Çoban", and "Prens Yankl" children's channels are limited to 1 video that contains advertising content and is chosen for the purpose. The reason why the number of subscribers of Child YouTubers is limited to 1 million in the research is that they have enough subscribers to produce sponsored advertisement content.

As a result of the study, it has been observed that the advertising content produced by child users on social media is especially aimed at the target audience of children and toys are examined regardless of gender. Girls' content producers have toys for boys, and boys' content producers; It was seen that he examined the toys for girls. In this case, when it comes to children, it has been concluded that advertising content produced for a fee or free product is highly preferable by children.

\section{Kaynakça}

Aksoy, E. (2018). Sosyal medya içeriklerinin marka takipçileri ile bă̆ kurma üzerine etkisi: Markaların facebook gönderileri üzerine bir içerik analizi. Anadolu Üniversitesi, İşletme Anabilim Dalı, Yüksek Lisans Tezi, Eskişehir.

Asmussen, B., Wider, S., Williams, R., Stevenson, N. and Whitehead, E. (2016). Defining branded content for the Digital Age: The industry experts' views on branded content as a new marketing communications concept. Oxford Brookes University. Londra: Branded Content Marketing Association. Erişim: https://www.thebcma.info/wp-content/uploads/2016/07/BCMA-ResearchReport_FINAL.pdf

Atalay, G. E. (2019). Sosyal medya ve çocuk: Babishko Family Fun TV. Erciyes Illetişim Dergisi Uluslararası Dijital Çă̆da İletişim Sempozyumu Özel Sayısı, 179-201.

Büyüköztürk, Ş., Çakmak, E., Akgün, Ö.E, Karadeniz, Ş., Demirel, F. (2008). Bilimsel araştırma yöntemleri. (13. Baskı), Ankara: Pagem Akademi,

Charitsis, V. (2016). Prosuming (the) self. Ephemera: Theory \& Politics in Organization, 16(3), 37-59. 
Çalışkan, S. (2014). Üreten tüketicinin yükselişi: Kullanıcıların ürettiği reklamlar. İnönü Üniversitesi, İletişim Bilimleri Anabilim Dalı, Yüksek Lisans Tezi, Malatya.

Çetin, B. N. (2019). Üretüketim olgusu bağlamında örtülü emek olarak dijital üretüketici emeği. Sosyal Siyaset Konferansları Dergisi, 77, 349-382.

Güney, Z. (2010) Çoklu medya ortamında üreten tüketici reklamcılı̆̆ı. Marmara Üniversitesi, İletişim Bilimleri Anabilim Dalı, Doktora Tezi, İstanbul.

Halbert, D. (2009). Mass culture and the culture of the masses: A manifesto for usergenerated rights. The Vanderbilt Journal of Entertainment and Technology Law, 11(4), 921-961.

Handley, A. (2014). Herkes yazabilir. (2. Bask1). İstanbul: MediaCat Kitapları.

Horrigan, D. (2009). Branded content: A new model for driving tourism via film and branding strategies. Tourismos: An International Multidiciplinary Journal of Tourism, 3(4), 51-65.

Koçak, A. ve Arun, Ö. (2007). İçerik analizi çalışmalarında örneklem sorunu. Selçuk İletişim Dergisi, 4(3),21-28.

Kotler, P. (1986). The prosumer movement: a new challenge for marketing. Advances in Consumer Research, 13, 510-513.

Krakowiak, M. and Modlinski, A. (2020). Popularity of branded content in social media. Journal of Computer Information Systems, 4(60), 309-315.

Krishnamurthy, S. and Dou, W. (2015). Note from special issue editors: Advertising with user-generated content: A framework and reseach agenda, Journal of Interactive Advertising, 8(2), 1-4.

Leaver, T. (2015). Born digital? Presence, privacy, and intimate surveillance. ReOrientation: Translingual Transcultural Transmedia, 149-160.

Lessig, L. (2001). The future of ideas: The fate of the commons in a connected world, (1. Bask1). New York: Random House.

Lou, C. and Yuan, S. (2019). Influencer marketing: How message value and credibility affect consumer trust of branded content on social media. Journal of Interactive Advertising, 1(19), 58-73.

Newell, J., Salmon, C. T. and Chang S. (2006). The hidden history of product placement. Journal of Broadcasting \& Electronic Media, 50(4), 575-593.

Öztürk, C. (2014). Bilinçaltı reklamcılık ve göstergebilimsel reklam analizleri. Beykent Üniversitesi, Sosyal Bilimler Enstitüsü, İletişim ve Tasarım Anabilim Dalı, Yüksek Lisans Tezi, İstanbul.

T.C. Resmî Gazete, Ticari Reklam ve Haksız Ticari Uygulamalar Yönetmenliği, 10.01.2015 Resmî Gazete Sayısı: 292232.

Twenge, J. M., Campbell, S. M., Hoffman B. J. and Lance C. E. (2010). Generational differences in work values: Leisure and extrinsic values increasing, social and intrinsic values decreasing. Journal of Management, 36(5), 1117-1142.

Ünal, A. T. ve Deniz, L. (2020). Sosyal medya kuşaklarının sosyal medya kullanım seviyeleri ve tercihleri. Uluslararası Toplum Araştırmaları Dergisi, 15(22), 12901319. 
Weinberg, T. (2012). The new community rules: Marketing on the social Web. Journal of Applied Communications, 96(2), 11-13.

\section{İnternet Kaynakları}

Çağıltay, K., (2016). İnternetle tanışma yaşı bakın kaça düştü, TRT Haber, https://www.trthaber.com/haber/yasam/internetle-tanisma-yasi-bakin-kaca-dustu241487.html Erişim Tarihi: 14.03.2021.

Habertürk, 6-15 yaş arası çocuklarda internet kullanımı yüzde 70'leri aştı "çocuklarda teknoloji bağımlılığı ve sosyal medya kullanımı" semineri, <https://www.haberturk.com/samsun-haberleri/68236354-6-15-yas-arasicocuklarda-internet-kullanimi-yuzde-70leri-asticocuklarda-teknoloji, Erişim Tarihi: 20.01.2021.

We Are Social (2020). Digital 2020 Turkey, https://datareportal.com/reports/digital-2020turkey Erişim Tarihi: 05.01.2021.

Youtube (2014). Oyuncak Av1 YouTube Kanal1, https://www.youtube.com/c/ OyuncakAvıTV/videos, Erişim Tarihi: 07.06.2021.

Youtube (2015). Prens Yank1 YouTube Kanal1, https://www.youtube.com/c/ Kosifler/videos Erişim Tarihi: 07.06.2021.

Youtube (2016). Ecrin Su Çoban YouTube Kanal1, https://www.youtube.com/c/ ecrinsucoban/videos Erişim Tarihi: 06.06.2021.

Youtube (2017). Prenses Lina TV YouTube Kanal1,https://www.youtube.com/c/ PrensesLinaTv/videos Erişim Tarihi:08.06.2021.

Youtube (2018). Ecrin Su Çoban kanalının, Yer misin? İçer misin? | Puding benim şarkımsa, milkshake benim dansım!, https://www.youtube.com/watch?v=TAjM7HKHHdE Erişim Tarihi: 07.06.2021.

Youtube (2018). Oyuncak Avı kanalının Öykü Num Noms tutkusu learn colors with me and watch num noms Play Time, https://www.youtube.com/watch?v=OEfJJhol_2s Erişim Tarihi: 07.06.2021.

Youtube (2018). Prens Yankı kanalının, Yankı ile çocuk oyunlarından buz kırma oyunu oynuyoruz, https://www.youtube.com/watch?v =RyeblEZrjaw, Erişim Tarihi: 16.05.2021.

Youtube, YouTube Kids Uygulamas1 (2018). https://creatoracademy. youtube.com/page/lesson/kids-app, Erişim Tarihi: 20.12.2020.

Youtube (2019). Vlad ve Nikita YouTube Kanal1, https://www.youtube.com/ channel/UCsZoAGyfzP1v5Z2BWyDU1kA/videos Erişim Tarihi: 08.06.2021.

Youtube (2021). Vlad ve Nikita kanalının, Vlad ve Niki oyuncak kamyonlarla eğleniyor | Hot Wheels Canavar Kamyonlar, https://www.youtube.com/watch?v=fQiyOc9KITA Erişim Tarihi: 08.06.2021.

Youtube (2021). Prenses Lina TV kanalının, Danone Mix yiyen Lina'nın elbisesi Frozen Elsa kostümlerine dönüştü!, https://www.youtube.com/watch?v=oR5XcTGOJZA Erişim Tarihi: 06.06.2021. 
Araştırmacı Katkı Oranı: Araştırmacılar çalışmaya eşit oranda katkı sunmuştur.

Destekleyen Kurum/Kuruluşlar: Herhangi bir kurum/kuruluştan destek alınmamıştır.

Çıkar Çatışması: Herhangi bir çıkar çatışması bulunmamaktadır. 